\title{
The Influence of Fishing Assets and Migration Time to Catch Squid Fisheries on Seasons Variability
}

\author{
Dewi Susiloningtyas, Mennopatria Boer, Luky Adrianto, Fredinand Julianto
}

Received: 3103 2014/ Accepted: 16042014 / Published online: 30062014

(๑) 2014 Faculty of Geography UGM and The Indonesian Geographers Association

\begin{abstract}
This paper was based on primary data from Lombok squid fishermen communities. The presence of fisherman migrants in fishing activities at salura island is very important for their livelihood. The purpose of this study was determined the catch in different season influenced by the duration time of migration and fishing assets. Fishing assets described of number of fishing gear, number of boat, and number of engine. Duration time described are length of stay at located of migration and frequency of migration. Data were analyzed by regression statistic analysis. The results is that fishing assets of fishing gear have influenced to cacth both on east monsoon and west monsoon season. Then length of stay at the destination of migration affect the catch too, when the squid are abundant in the east monsoon season.
\end{abstract}

Keywords: Fishing assets, Salura island, seasons variability, squid fishermen.

\begin{abstract}
Abstrak Makalah ini didasarkan pada analisa data primer dari nelayan migran cumi-cumi Lombok. Kehadiran migran nelayan dalam kegiatan perikanan di Pulau Salura sangat penting untuk mata pencaharian mereka. Tujuan dari penelitian ini adalah mengetahui jumlah tangkapan di musim yang berbeda dipengaruhi oleh durasi waktu migrasi dan aset perikanan untuk aktifitas penangkapan. Aset perikanan digambarkan dari jumlah alat tangkap, jumlah kapal, dan jumlah mesin. Durasi waktu dijelaskan dari lama tinggal di tempat migrasi dan frekuensi migrasi. Data dianalisis dengan analisis statistik regresi. Hasil menunjukan bahwa aset perikanan/alat tangkap telah mempengaruhi jumlah tangkapan ikan baik pada musim timur dan musim barat. Lama tinggal di daerah tujuan migrasi turut mempengaruhi hasil tangkapan, yaitu pada saat musim timur, dimanaterjadi kelimpahan cumi-cumi.
\end{abstract}

Kata kunci: Aset perikanan, Pulau Salura, variabilitas musiman, nelayan cumi.

\section{Introduction}

Squid fishermen from Tanjung Luar Lombok have fisheries activities at their own local marine, but with a few problems, the fishing starting to move to the further away from the marine where they lives. Since 1995, they catch up of squid to salura island at East Sumba Province which is different from region with their homeland (based on talking with Koneng, who is old fishermen of migration to Salura). They have problems and limitations condition were the wheather condition do not support, filling activities outside peak fishing, overfishing and the catching of fish resources in the area, so reducing the production of fish. It is at the background of the movement of seasonal squid fishing. This condition resulted in local squid fishermen have do migration for catch of squid, even down to the Salura Island, Eastern Sumba (at Province of Nusa Tenggara Timur). In the process of fishing migration will affect the sustainability of the resources. This is due to the vulnerability of ecological damage on the squid migration path traversed, in addition to the exixtence of conflicts of immigrant community and local people at the desti-

\footnotetext{
D. Susiloningtyas

Department of Geography, University of Indonesia, Jakarta

dewi.susiloningtyas@ui.ac.id
}

M.Boer, L. Adrianto, F.Julianto

Department of Coastal and Marine Resource Management, Bogor

Agricultural University, Bogor nation areas. Facts about the uniqueness of this communities in fishing activities will be explored in this study.

The seasonal migration of the migrant squid fishermen in west monsoon season and east monsoon season are well phenomena of which especially monsoon seasonal migration has got attention. The migrant fishermen developed strategy for the different seasonal condition. Decision to migrate depend on expectation and capital assets which can be used to support of fishing [De-Haan, 1999; De-Haan, 2006]. Ellis [2003] indicated about migration as an important component of livelihood strategies within the broad literature and development, despite the limited attention given it. Fiona [2010] indicated that motivation for migration is generally the search for better catches and profits in new locations, this does raise issues of over exploitation, with challenges for fisheries management in term of managing capacity. There is therefore a seasonal dimension to fishermen migration, although movement can also become part of cultural. There are four forms of migration in relation to agricultural livelihoods, seasonal, circular, permanent and international [Ellis, 2000]. There are differrences meaning of the migration concepts. According to Randall [2005] and Overa [2001], spesifically in relation to migration within fisheries, refer to both seasonal and circular migration. Overa [2001] have description of both concepts. Seasonal migration being resources related, whereas cir- 
cular migration is seen as less dependent on the resource than on economic and political conditions. In general concepts, based on Deshingkar and Start [2009], seasonal and circular migration of labour for employment has become one of the most durable components of the livelihoods strategies. Randall [2005] also concludes that movements takes many forms and that motives for moving are diverse and are not due to movement of fish alone. Randall [2005] suggest that whilist following fish movements may have been essensial in the past, movement has been retaised as a livelihoods strategy and other economic benefit are gained from moving.

Jeffrey and Michael [1990] sayed that migratory fishing patterns are found to depend on a combination of physical, occupational, economic, political and social structural factors. They note about case of fishing patterns too. In some cases these migratory patterns of vessel and labour movement occur because of the migratory nature of the fishing resource itself (ie. Salmon, tuna and swordfish), but in the case movement and patterns are created by political or administrative decisions, so there are identified 5 factors influencing interstate migration among fishermen, as social structure, economics, politics, feautures of work and of course, also the environment [Jeffrey and Michael, 1990]. In this reseach seasonal migration by fishermen influenced by social structure, economic, and the environment.

Most of squid fishermen at salura island as a bajo traditional fishermen. Stacey [2007] says about Bajo Fishermen at Indonesia. Bajo activity usually as a traditional fishermen using traditional methods. Their activities by the activities with traditional methods, and using the $t$ raditional boat for go to fishing ground. Fabian [1982] in Stacey [2001] have interpretation of "traditional". The means of traditional refer to less technology and characteristised by subsistence economies and simple technology. Migrant fishermen like as squid fishermen at salura island have risk of wheather and cyclones, because only using traditional boat for far trip of their activities fishing.

\section{The Methods}

Study area is in the coastal region of Salura Island at East Sumba Province as destination area. As a for the fisherman who fishing communities of Tanjung Luar at Lombok Island as origin area. The adminstration, Tanjung Luar and Salura Island are two diferent location provinces. Tanjung Luar inside to Nusa Tenggara Barat Province and administration of Salura Island is Nusa Tenggara Timur Province. Salura Island is location of fisherman who do seasonal migration which is in the coastal fishing village on the island of Salura. Salura Island is one of the small outer islands in Indonesia. Located on the southeastern island of Sumba Island. As a administrative area, Salura village located in Karera District of East Sumba Province. Salura Island inhabited by 568 population and the number of household is 138. Pupulaiton density is 52 people each $\mathrm{km}^{2}$. Salura Island is surrounded by The Indian Ocean Coast has sloping topography in the north and step in the south. Most of the land is hilly rocks form and only about
$25 \%$ of land inhabited plains Salura village community. Salura Island have $14,83 \mathrm{sq} \mathrm{km}$ with extensif reef area is $20,64 \mathrm{sq} \mathrm{km}$. The absolute distance Tanjung Luar to Salura Island is $495 \mathrm{~km}$. The time required by the migrant fishermen to get into the Salura Island is around 3 days. Squid Migrant Fishermant through different province. As a ecollogicaly and geomorphology aspects, Salura Island is a coral island that directly open exposure with Hindia Ocean. The dominant of geomorphological structure is the process sedimentary of limestone.

This approach of research is using survey methods, that research using questionair and interview guidlines for data collection, so related with determaining of variables like fishing characteristics and fishing activities. As for the respondent is migrant communities who do squid fishing activities at Salura Island. The number of respondent is 35 fishermen consisting of owned fishermen with high fishing assets, medium and low fishing assets. The data collected is a variable that can described the capital assets as a number of boats, number of fishing gear and also number of mechine of boats. The data fishing activities concist are quantity of squid of catch, also collected data of migration characteristics which described duration time of migration like as frequency migration and length stay of migration. This research data collection methods used in survey research with questionair for get of primary data and also supported by secondary data from institution and interview with key informant.

Selection respondent for fihermen used by Probability sampling with systematic random sampling technique. Probability sampling is a sampling for selection of respondent, that respondents consider that every element in the population has the same probability to be sampled. As for the technique used is systematic probability sampling in which each element in the population has the same probability to be recognized and selected. This method is used because the population is logically considered homogenous. Systematic sample units are uniformly on all fishermen. correlation between catch and with fishing assets, also and duration of migration based on variation season. The results of analysis to know how differences characteristics of catch with capital assets and duration migration in variation season, as west and east monsoon season.

At the beginning of the study had obtained information that a number of fishermen who recorded was 350 fishermen, then the process in sampling study determined ten percent of the total population, selected for 35 migrant fishermen. Fishermen to determine who is selected around 35 fishermen then used random sampling. There are 5 fishermen every group or team of fishing activities. The number of respondents who will be taken to represent the population data and approriate reseach objectives. This is case study of research, so it is possible to examine the small sample size, especially if the population is relatively homogeneous.

Regresion analysis used in the study is to examine the correlation between catch and with fishing assets, also and duration of migration based on variation season. The results of analysis to know how differences characteris- 


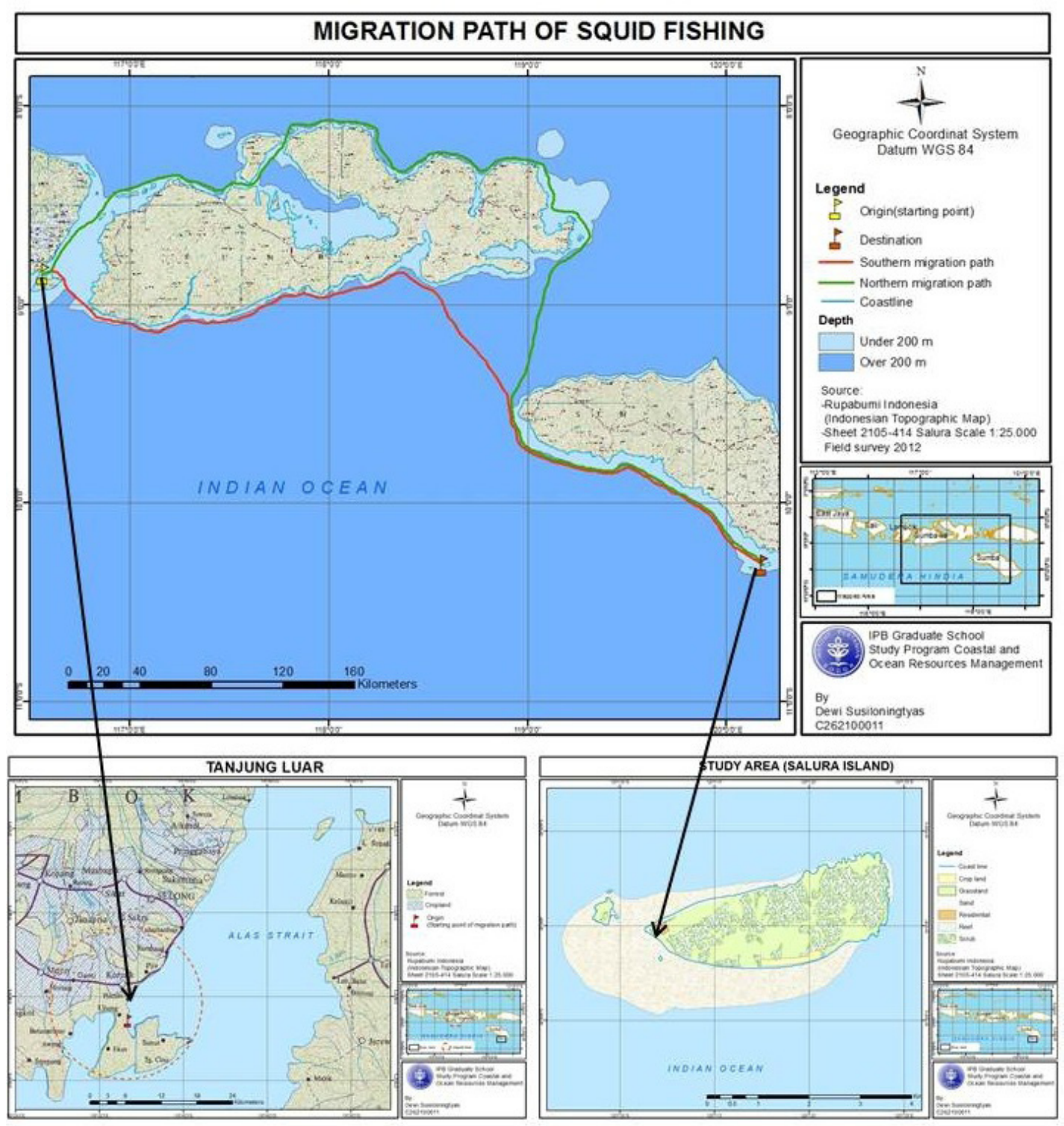

Figure 1. Study Area and Route Squid Fishermen from Origin Areas (Tanjung Luar Lombok Island) to Destination Areas (Salura Island, Sumba)

tics of catch with capital assets and duration migration in variation season, as west and east monsoon season.

\section{Result and Discussion}

The geographical setting of Salura Island is positioned between Australia and Asia continents, also between Indian and Pacific Oceans (Figure 1). Salura Island is a part of the Sawu Sea, so climatology of Salura have same the others island of archipelagic areas in Sawu Sea. Salura as part of the sawu sea oceans have a very dinamic flow condition, as are the two great currents, Indian Oceans and Banda Sea. All of this condition, salura oceans as a high productivities areas. Seasonal variations can be description from the wave condition. There were two season of variation, east monsoon and west monsoon season. The wave condition during the season have different of both. Charactetristics of seasons have affect of catch and fishing.
Climatic conditions in the region known as the sawu sea have two climate patterns that is dry season and the rainy season. On june until september, the wind came from australia and does not contain much moisture. The local name is "musim kemarau", as a dry season. Different condition with january until march and also december, on these months have a wet season or "musim hujan" for local name. The Wind coming from asia and pacific oceans, although have much of moisture, but it was reduce when it reached the water of sawu sea. This is due to the influenced of Australia continent. Transition season at sawu sea is between april - mei and october - november.

Wet during the west monsoon season, that wave came from India Oceans entrance to Sawu Sea oceans and then hit the explosure beach like as western beach and sothwestern coast. The beach is on the Timor Island, Rote island, Sabu island and Sumba Island. Winds from the north are moving to the oceans and deflected to the 
east and southeast.Its would generated waves of the west and northwest towads the small island in the south.

At the time, moved of the wind came from the south as a India Oceans. The waves came into the oceans of sawu sea, and also hit to front of coastal areas, like as Timor Island, Rote Island, Sabu Island and Sumba Island. There are phenomenon of waves from hindia oceans from south would be deflected toward to west and northwest. This phenomenon led to generated of east wind and southeast wind toward Flores Island and Sumba Island.

Based on its geographical location, Salura island have position between Australia and Asia continents, also between Indian and Pacific Oceans. Salura Island is a part of the Sawu Sea, so climatology of Salura have same the others island of archipelagic areas in Sawu Sea. Salura as part of the sawu sea oceans have a very dinamic flow condition, as are the two great currents, Indian Oceans and Banda Sea. All of this condition, salura oceans as a high productivities areas. Seasonal variations can be description from the wave condition. There were two season of variation, east monsoon and west monsoon season. The wave condition during the season have different of both. Charactetristics of seasons have affect of catch and fishing.

Fishermen catch was different related seasonal condition. This matter by influenced with west monsoon season, east season monsoon and also transition monsoon season. The results showed that abundance of squid catch was when the wind came east monsoon season, which was June, July, September, October and November. When the wind came west monsoon season, fishermen did not even dare to do the activity, which periodec months was in december, january to february. While at the transition period season such as march to may, only in certain months, they make arrest, which was arround the month of may. Refer to data from marine fisheries department in 2012 to catch squid statistics (Figure 2) showed that the catch squid in the east monsoon period was the highest catches in november, as many as $31,650 \mathrm{~kg}$, while in the period of the season was the period of lowest catch in june ammounted to $6,757 \mathrm{~kg}$.
Condition during the west season showed that a decline in the fishermen catch. Optimally catch only occurs during December, with the catch of $9000 \mathrm{~kg}$. The period of january and february tend to be no catch at all. On January and February was estimated that fishermen can not go to sea due to the wind conditions and high waves, so that by the time period this month because can not go to sea wave conditions and high winds. During the period of this month fishermen not to migrate to catch squid, but did arrest activity at the place of Tanjung Luar at homeland.

The next Seasonal catch category was occur on transitional season. Transitional season was at the time of the change of seasons from west to east monsoon season. In this period showed that the optimal arrest occured only in may, which was the catch obtained at 3,500 kg. This amount was relatively very small when compared with the catch in the event of the east monsoon season.

Based on primary data that catch squid for seasonal variations have the diffference of dinamic and fluctuatif condition. On figure 3 that when the season is abundant squid, average of catchment is $662.9 \mathrm{~kg}$. Then not abundant squid was reduces to an average of $54.4 \mathrm{~kg}$. If related with the arrest of squid fishing season, it would seem that when the squid are abundant during migration of fishermen from Tanjung Luar to Salura island in september, october and november.

Fishing assets holdings for goods that support fisheries productivity can support fishing activities. The forms of fishing assets can be a number of units of boat ownership, the number of fishing gear, as well as capital assets of the boat mechine engine. Characteristics of fishermen in fishing assets was very different. Some fishermen even had to hire a fishing boat to arrest the fishing activities.

Refer to result of this research on the number of boats owned assets was seen that most of the fishermen with the ownership assets was lower by $43.7 \%$ which the price of boats was less than 29 million rupiah each unit of boath. Beeing followed by assets category was medium at $31.3 \%$ with total assets ammounting

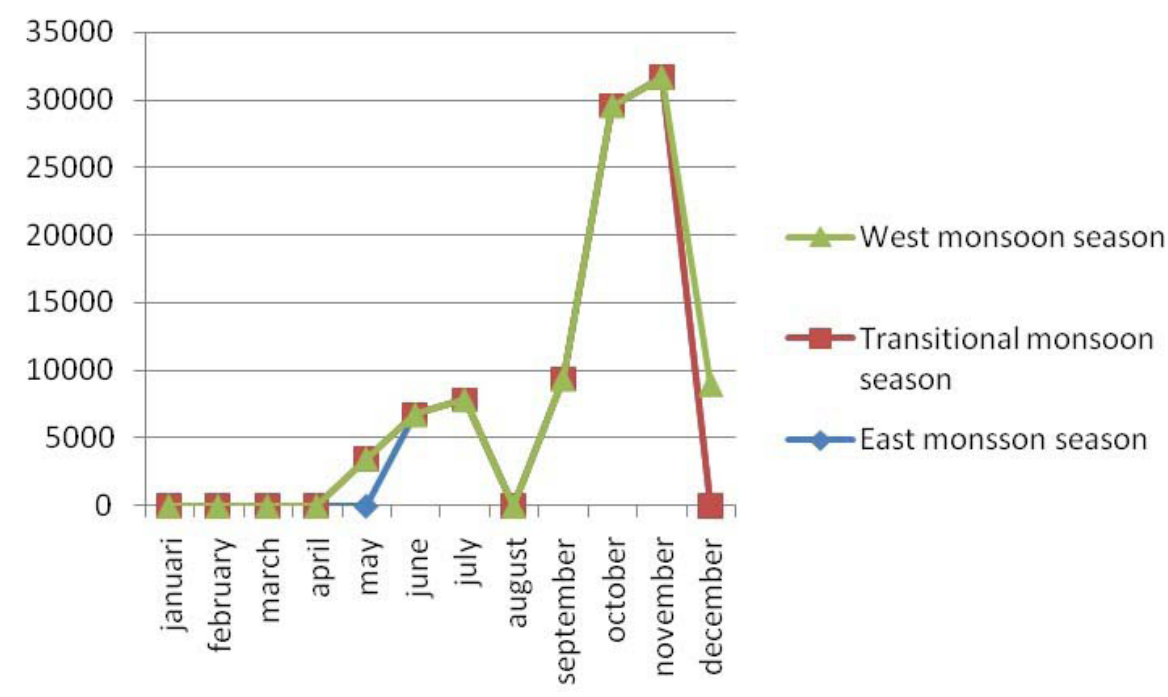

Figure 2. Secondary data of squid catch on variation season $(\mathrm{kg})$ 


\section{Catch on Variation Season}

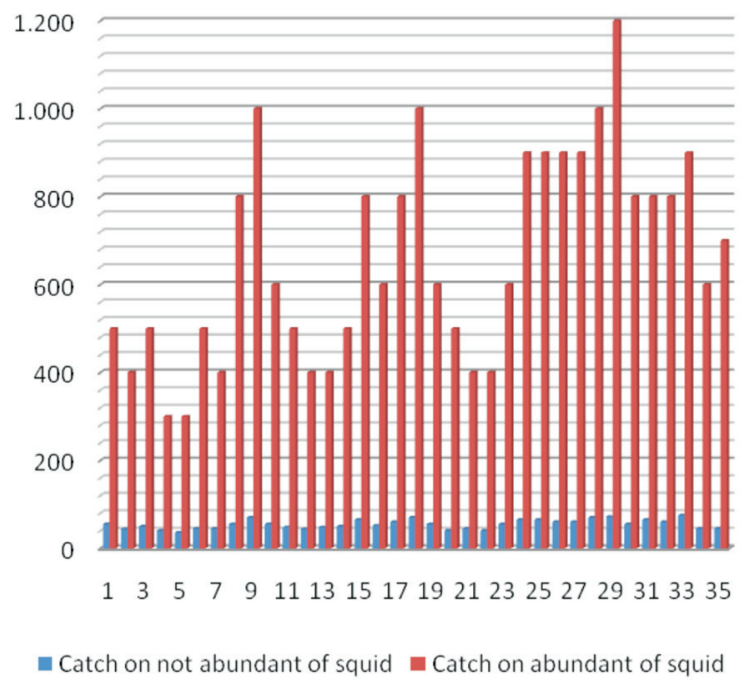

Column1

\begin{tabular}{lr}
\hline \multicolumn{1}{c}{ Column 1} \\
\hline \\
Mean & 662,9 \\
Standard Error & 39,8 \\
Median & 600 \\
Mode & 500 \\
Standard Deviation & 235,3 \\
Sample Variance & 55344,5 \\
Kurtosis & $-0,9$ \\
Skewness & 0,3 \\
Range & 900 \\
Minimum & 300 \\
Maximum & 1200 \\
Sum & 23200 \\
Count & 35 \\
\hline
\end{tabular}

662,9

39,8

5344,5

$-0,9$

0,3

900

35

Figure 3. Squid catch on variation season $(\mathrm{kg})$

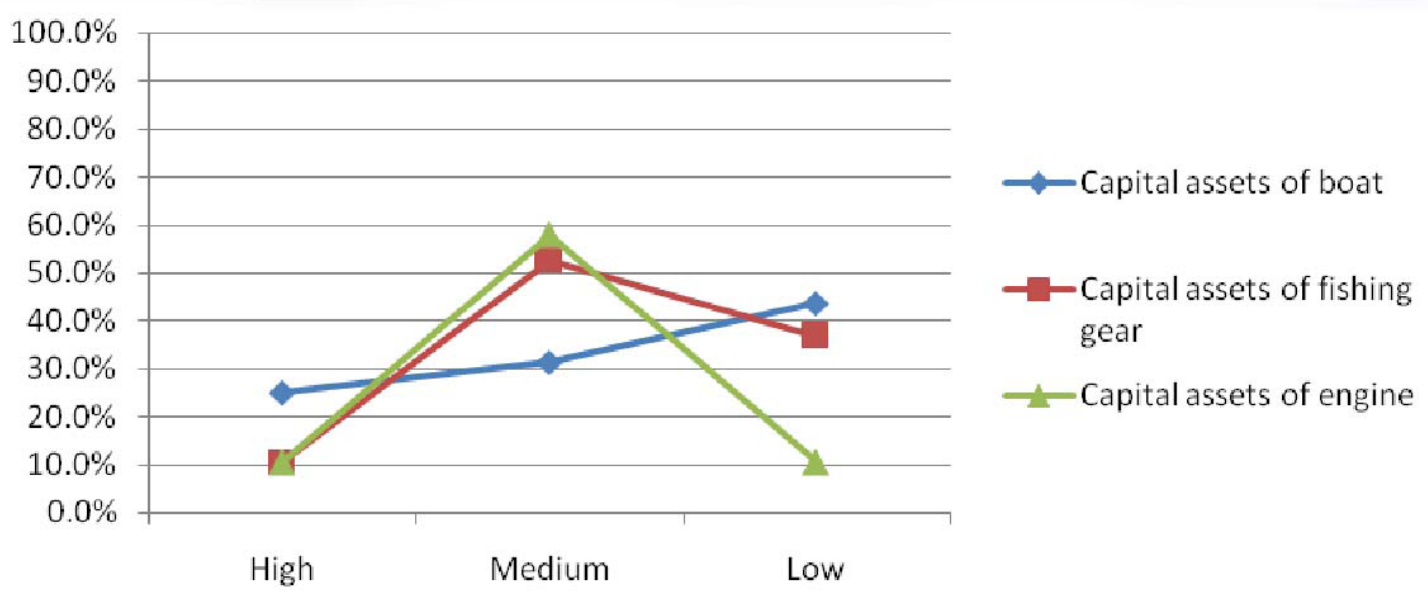

Figure 4. Percentage variation of fishing assets

95 to 125 million rupiah. As for fishing with high assets capital of boats occupied the smallest amount was only $25 \%$ of an assets of over 126 million each unit.

Indicator of fishing assets can be determined also from ownership of the number of fishing gear. The number and least amount of fishing gear used can be affect the catch. Type of fishing gear for fishing was a kind of chart that was in the form of net fishing gear, accidentally lowered into the sea, then it will be pulled up after squid collected, then there was also a fishing rod that was ussualy very special to catch squid. This type of fishing gear was rarely used. Determinant of capital assets was the third indicator of the number of machines. Boat of mechines in a very important for fishing, which was to achieve a smooth fishermen fishing ground so that no damaged of boat in the incident.

Figure 4 shows that the majority ownership of the boat has a low asset values, which only has 1 unit boat. This is different with fishing assest of fishing gear, most of the holding are categorized mod- erate on 6 - 9 units of fishing gear, reaching $52,6 \%$. As for assets of mechine, mostly in the category of medium of fishing assets, which reached 57,9\%.

Seasonal migration patterns made by migrant fishermen can be identified from a many indicators related their spend time for migration activities. These indicator like as length stay each time to migrated and migration frequency within one year, like as on Figure 5.

Based on the intensity of the migration time, it appears that the frequency of $88.6 \%$ perform migration with moderate category which is 9 time within of periode 1 year on April until december. As for the low and moderate frequency have the same value as $5.7 \%$.

Most of the migrant fishermen in a single trip journey lived at destination of migration areas average 6 to 10 days. Migration patterns with length of stay was included in the category of being migration pattern was mostly done by fishermen, which reached $65.7 \%$. As for the category of length of stay more 
than 11 days was $22.9 \%$ while for a short length of stay category was less than 5 days was equal to $11.4 \%$.

This study proves what catches during the west monsoon and east monsoon season related with duration time of migration and capital assets. The hypothesis formulated is that there are differences in the catch based on length of stay and frequency of migration is done, as well as to the capital assets of boat, fishing gear and mechine.

Statistical results of the correlation between the variation of the catch on the eastern season period could be seen on Table 1, which was indicated by the number of squid abundance with the intensity of migration frequency aspects of migration turns positive correlation, but the factor is often whether or not they perform the migration was not reliable to see the difference in the catch. This was due to the statistical test results obtained from that significance F (0.532) was greater than significance level (0.05), that rejected hypothesis expected and accepted hypothesis nol (Ho) that there was no defferences in the catch based on migration frequency of fishermen.

To test the correlation between variations in the catch squid in the east when the season turns out the results that the value of $\mathrm{P}$ sinificance that was equal to 0.03 smaller than probability 0.05 . This means that the hypothesis of the statement was accepted $\mathrm{H} 1$ and rejected for Ho. There are differences the intensity of the catch with time or a long stay in the area of destination of migration. The many time intensity of length of stay at destination area of migration it will be higher of catch obtained.

In the west monsoon season, the catch of fishermen were very much reduced than when abundant squid season, when the east monsoon season.On the wast monsoon season will be test the relationship between the intensity of the catch with the migration pattern. The prediction variables on east season of frequency and length of stay not same significant. The Pvalue for length of stay (0.02) is significant, becauese have a low $\mathrm{p}$-value $(<0.05)$. A low $\mathrm{p}$-value indicates that reject the null hypothesis, the meaning is length of stay to be a meaningfull addition to model, because changes in the predictor's value are related to changes in the catch variable. This is different with frequency migration variable $(0.53)$, that is greater than the common alpha (0.05), which indicates that is not statistically significant. But on west monsoon season both of their $\mathrm{p}$ values are greater than alpha level (0.05), which indeicates is not statistically significant too, as likely to be a meaningful changes in the predictor's value are not assosiated with changes in the response variable.

High intensity of the reflected migration and lack of time or a lot of intensity where the intensity was a combination of variable migration frequency and length of stay at the destination. With the regresion analysis of this correlation can be seen either individually or together to influence the produktivity of catch. Statistical test results stating that there was no difference in the results obtained when fishing intensity correlated with the frequency of migration of fishermen. Calculated value (0.140) is smaller than F table (47.399), it was also confirmed from the significant value of $\mathrm{F}$
(0.711) greater than 0.05 significance of level. Concluded that the results of testing between these two variables was to accept the hypothesis Ho and rejected $\mathrm{H} 1$.

If the catch correlated with the intensity of the aspect of length of stay at destination area of migration , it could be concluded that thesignificance of the values obtained, and of the value of F counted, then this was a test between variable accepted ho and rejected H1. This means that there no difference in the catch of squid during the west monsoon season based on length of stay at the destination area of migration. The calculated F value was 0.140 and the value of $F$ table with 33 degree of freedom (df) was 47.399, while the significance of the $\mathrm{P}$ value was 0.110 greater than 0.05 .

Correlation between the catch in the east monsoon season with capital assets of boats correlations that were not so obvious, because the value of $\mathrm{R}$ square is generated from 1 which was about 0.196 . Then also if tested by comparing the value of significance turns Sig F value is greater than 0.05 , was equal to 0.258 . Likewise, if viewed from the calculated F value (1.324) and F table (47.39) which means that the calculated $\mathrm{F}$ is less than $\mathrm{F}$ table, so accepted Ho and rejected H1. This relationship appears that the difference does not affect the ownership of boats fishing catch. This is due to that the arrest of activity is ussually a team or group that was using a ship owned by one of the fishermen in the team or the ship's owner.

Correlation of the catch with the other capital assets, namely the capital of fishing gear. Results of the correlation between the catch by fishing gear ownership showed a positive relationship tends to be very strong and that is value of chi square (0.52) correlation is close 1 , while significant value obtained was 0.001 which is less than 0.05 . Conclusions that can be explained was that the Ho statement that says that there is no difference in the catch based on the number of fishing gear used to be rejected and accepted H1. This means that the statistical test states that there are differences in the results obtained fishermen catch squid as there are differences in the ammount of fishing gear used.

Result of subsequent statistical test was the correlation between the catch with capital assets of ship engines. Correlation the two suggest a relationship, but not strongly correlated because $\mathrm{R}$ obtained by 0.049 , which relatively far away approaching the $\mathrm{R}$ value of 1 . As for when seen from the significant value of $F$, which has a value of 0.78 is greater than 0.05 as the probability level. It can be concluded that this test received reject $\mathrm{Ho}$ and $\mathrm{H} 1$, which means that there is no difference in the catch based on ownership of capital assets of aspect of ship engines.

Statistical results for the relationship between the variables of catch with capital assets during the west monsoon season can be seen in the Table 2. Statistical test of the correlation between catch and capital assets of boat, fishing gear also ship engine, which is indicated by the value of $\mathrm{R}$ is still far away approaching 1. As for when viewed from its significance $F$ compared with 0.05 significance level, apparently of a third variable has a value of more than degree level there, so that Ho was accepted and $\mathrm{H} 1$ was re- 
jected. The conclusion that there was no difference in the catch based on ownership of capital assets of the ownership of boat, fishing gear and also ship engine.

\section{Conclusions}

Seasonal migrations undertaken by migrant fishermen from Tanjung Luar Lombok to Salura Island Sumba depends on the seasons variation, even the existence of this seasons variation was very influence on the catch. East monsoon during the sea- son when abundant of squid, the catch obtained strongly influenced by the amount of capital assests of fishing gear. This means that the higher the assets of fishing gear, so the results of catch will be over.

Length of stay in the destination area of migration also affect the results obtained arrest. Especially when the squid area abundant in the eastern monsoon season. This proves that there are indications that the current abundance of squid fishermen will stay longer in the area of migration and undertake resource explo-

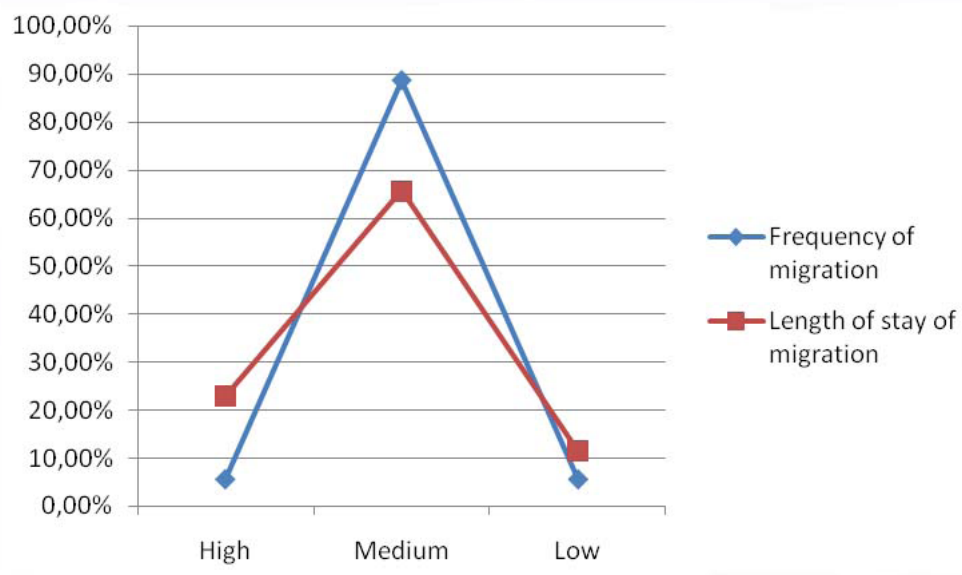

Figure 5. Percentage variation of duration time of migration

Table 1. Results from the ANOVA statistics from correlation between seasons variability of catch and duration time of migration patterns ( $\mathrm{n}=35$ fishermen)

\begin{tabular}{|c|c|c|c|c|c|}
\hline Variable & Source & df & MS & $\mathbf{F}$ & $\mathbf{P}$ \\
\hline \multirow[t]{6}{*}{$\begin{array}{l}\text { Catch on east monsoon } \\
\text { season }\end{array}$} & $\begin{array}{l}\text { Frequency of migration } \\
(\mathrm{x} 1)\end{array}$ & 3 & & & \\
\hline & 22.50 & & & & \\
\hline & 0.40 & & & & \\
\hline & 0.53 & & & & \\
\hline & $\begin{array}{l}\text { Length of stay of migration } \\
\text { (x2) }\end{array}$ & 3 & 26.48 & 5.40 & $0.02^{*}$ \\
\hline & $\mathrm{x} 1 \& \mathrm{x} 2$ & 3 & 49.82 & 2.88 & 0.07 \\
\hline \multirow[t]{5}{*}{$\begin{array}{l}\text { Catch on west monsoon } \\
\text { season }\end{array}$} & $\begin{array}{l}\text { Frequency of migration } \\
\text { (x1) }\end{array}$ & & & & \\
\hline & 3 & & & & \\
\hline & 16.00 & 0.14 & 0.71 & & \\
\hline & $\begin{array}{l}\text { Length of stay of } \\
\text { migration }(\mathrm{x} 2)\end{array}$ & 3 & 285.40 & 2.69 & 0.11 \\
\hline & $\mathrm{x} 1 \& \mathrm{x} 2$ & 2 & 150.70 & 1.38 & 0.27 \\
\hline
\end{tabular}

** Significant at $\mathrm{P}<0.01$ level

* Significant at $\mathrm{P}<0.05$ level 
Table 2. Results from the ANOVA statistics from correlation between seasons variability of catch and fishing assets

( $\mathrm{n}=35$ fishermen $)$

\begin{tabular}{llrrrr}
\hline Variable & Source & df & MS & F & P \\
\hline $\begin{array}{l}\text { Catch on east } \\
\text { monsoon season }\end{array}$ & Fishing assets of boat (x1) & 33 & 72.64 & 1.32 & 0.26 \\
& & & & & \\
& Fishing assets of fishing gear (x2) & 33 & 512.13 & 12.34 & $0.00^{* *}$ \\
& Fishing assets of engine (x3) & 33 & 46.92 & 0.08 & 0.78 \\
& x1 \& x2 \& x3 & 31 & 248.86 & 6.79 & $0.00^{* *}$ \\
Catch on west & Fishing assets of boat (x1) & 33 & 180.50 & 1.65 & 0.20 \\
monsoon season & & & & 5.27 & $0.03^{*}$ \\
& Fishing assets of fishing gear (x2) & 33 & 521.30 & 0.41 & 0.48 \\
& Fishing assets of mechine engine (x3) & 32 & 57.90 & 0.51 & $0.02^{*}$ \\
\hline
\end{tabular}

$\star$ Significant at $\mathrm{P}<0.05$ level

** Significant at $\mathrm{P}<0.00$ level

ration. So of this phenomenon can be seen that at the time of squid abundance, resource no longer taken into account for sustainability maintaned. Should be important to consider how these fishermen how to keep the resources is the source of their livelihood. They also must to continue for their livelihood sustainability.

\section{References}

Cassels, S., Curran, S.R., \& Kramer, R. (2005), Do Migrants degrade coastal environment? Migration, natural resources extraction and poverty in North Sulawesi, Indonesia, Human Ecology 33(3): 329363.

Costanza, R., et al. (2001), Institutions, Ecosystems, and Sustainability, Lewis Publishers, USA.

De-Haan, A. (1999), Livelihoods and poverty the role of migration, A critical review of the migration literature, Journal of Development Studies 36 (2): 1- 47.

De-Haan, A. (2000), Migration, livelihoods and right: The relevance of migration in development policies, Social Development Working Paper, No.4. Department for International Development, London.

De-Haan, A. (2006), Migration in the development studies literature: Has it come out its marginallity? Research Paper, No.2006/19, UNU-Wider, Helsinki.

Deshingkar., Priya, S., \& Daniel (2009), Seasonal Migration for livelihoods in India, accumulation and exclusion, Overseas Development Institut.

Ellis, F. (2000), Rural Livelihood and Diversity in Developing Countries, Oxford University Press, Oxford.

Ellis, F. (2003), A Livelihood Approach to Migration and

\section{Acknowledgement}

Gratitude is addressed to Sandwich Like Program (PKPI) from Ministry of Education and Culture of Indonesia for the scolarship, and also thanks to Leibniz Center for Tropical Marine Ecology (ZMT) Bremen, Germany for their help in improving the manuscript.

Poverty Reduction Policies, Routledge, London.

Ellis, F., \& Freeman, H.A. (2005), Conceptual framework and overview of themes. In:Ellis, F., Freeman, H.A. (Eds). Rural Livelihoods and Poverty Reduction Policies, Routledge, London.

Jeffrey, C.J., \& Michael K.O. (1990), Migration Fishermen: a case study in interjuridistional natural resources management. Ocean and shoreline Management 13: 231-252.

Nunun, F. (2010), Mobility and fisherfolk livelihoods on lake victoria:Implications for vulnerability and risk, Geoforum 41: 776 - 785.

Overa, R. (2001), Institutions, Mobility and resilience in the Fante Migratory Fisheries of West Africa, Working Paper 2001:2, Chr, Michelsen Institute. Bergen, Norway.

Randall, S. (2005), Review of Literature in Fishing Migration in West Africa-From a Demographic Perspective. Sustainable Fisheries Livelihoods Progamme. FAO/DFID, Rome.

Stacey, N. (2007), Boats to burn: Bajo fishing activity in the Australian fishing zone, ANU E-Press: The Australian University, Canberra,Australia. 